\title{
PENGEMBANGAN TERPADU CITY TOUR SEMARAPURA MELALUI SHIP APPROACH
}

\author{
I Nengah Alit Nuriawan \\ Program Studi Magister Pariwisata, Fakultas Pariwisata Universitas Udayana \\ Email: alitnuriawan@unud.ac.id \\ Syamsul Alam Paturusi \\ Program Studi Magister Pariwisata, Fakultas Pariwisata Universitas Udayana \\ Email: syamsul_alam_paturusi@yahoo.fr \\ I Nyoman Sunarta \\ Program Studi Magister Pariwisata, Fakultas Pariwisata Universitas Udayana \\ Email: carins54@yahoo.com
}

\begin{abstract}
The development of Semarapura City Tourism through City Tour has not been running as expected, so it has not been able to increase foreign tourist arrivals and has not been able to improve the economy of the community. The research objective was to identify integrated development of City Tour City Semarapura tourism through the SHIP Approach. This study uses a qualitative descriptive approach. Data collection methods used in this study were observation and interviews. The theory used in this study is the Tourism Area Life-Cycle, explaining the position of development of Semarapura tourism. SHIP theory (systemic, holistic, interdiciplinary, and participatory) to describe and explain how the integrated development of City Tour in Semarapura City. The integrated form of City Tour tourism in Semarapura city is carried out by designing tourism models with improvements to the previous City Tour program and designing new tour packages, with additional classes for each package. Puppet painting class, weaving class, metal craft / kepeng money making class and brown sugar making class. The development of City Tour with the addition of tourist classes will provide experience for foreign tourists who visit and have a positive impact on the economy of the community through active participation from all stakeholders.
\end{abstract}

Keywords: Integrated development, Semarapura city tourism, SHIP Approach 


\section{Pendahuluan}

Kota Semarapura menjadi kota yang akan dikembangkan sebagai pusat pariwisata perkotaan di Klungkung. Semarapura menjadi pusat pemerintahan Kabupaten dan sumber kesenian budaya Bali. Sejarah mencatat bahwa seni (karawitan, ukiran, patung, arsitektur, wayang), tata upacara keagamaan dan budaya Bali lahir dan berpusat di Semarapura. Kertagosa, Museum Semarajaya, Puri Agung Klungkung dan Monumen Puputan Klungkung merupakan bangunan yang ada di Kota Semarapura, yang memiliki nilai historikal yang tinggi sehingga mampu memberikan daya tarik bagi wisatawan. Sejarah Kertha Gosa berawal dari keberadaan Puri Kerajaan Klungkung, yang merupakan kerajaan terakhir di Bali yang melakukan perlawanan terhadap kolonial Belanda (Sidemen, 2001:22-34).

Kertha Gosa digunakan sebagai media konservasi peninggalan bersejarah yang memiliki nilai kebudayaan yang tinggi dan media pembelajaran atau edukasi bagi wisatawan tentang sejarah kerajaan di Bali pada umumnya dan Klungkung pada khususnya. Agustinadewi (2017) dalam penelitiannya menyebutkan bahwa konservasi tidak hanya mencakup struktur bersejarah dan tempat-tempat bernilai sejarah, tetapi juga pada kondisinya. Semarapura memanfaatkan potensi sejarah yang dimiliki untuk dikonservasi melalui pengembangan pariwisata. Paturusi (2008) mengungkapkan pengembangan sebagai strategi untuk memperbaiki, memajukan dan meningkatkan kondisi kepariwisataan destinasi. Rossi dkk, (2012) menyatakan bahwa pengembangan pariwisata tidak selamanya memberikan dampak positif, namun juga memberikan dampak negatif khususnya terhadap lingkungan ditandai dengan adanya alih fungsi lahan.

Semarapura yang memiliki berbagai potensi wisata mulai dikembangkan pemerintah, salah satunya pada 29 April 2016 Pemerintah Kabupaten Klungkung meluncurkan paket wisata Semarapura City Tour. Menurut data Dinas Pariwisata (2016) bahwa City Tour memiliki rute dengan panjang 4 sampai dengan 6 kilometer, 
dengan waktu tempuh 15 menit yang dimulai dari Monumen Puputan Klungkung, kemudian ke Puri Agung Klungkung, dilanjutkan ke Museum Semarajaya, Pemedal Agung, Kertha Gosa, Pasar Seni Klungkung dan terakhir mengunjungi Desa Wisata Kamasan. Sedangkan dalam promosinya (Berita Bali 2017) Pemerintah Kabupaten Klungung telah bekerja sama dengan Association of The Indonesian Tours And Travel Agencies (ASITA).

Desa Wisata Kamasan salah satu desa wisata yang sudah dijangkau program City Tour telah dipersiapkan seperti ketersediaan informasi tentang keunggulan desa, baik mengenai potensi seni dan industri kreatif (Berita Bali 2017). Pengembangan City Tour dilakukan Pemerintah Kabupaten Klungkung salah satunya dengan menciptakan aplikasi smart city. Pemerintah meluncurkan aplikasi berbasis internet khusus dalam mencari informasi terkait pariwisata Klungkung yaitu aplikasi “Klungkung Tourism". Agus dkk (2015) menyebutkan bahwa pengembangan aplikasi berbasis android dapat membantu mengenalkan Kabupaten Klungkung dalam sektor Pariwisata.

Program City Tour di Kabupaten Klungkung telah di-launching dan diterapkan, namun keberadaannya belum berjalan optimal (Bali Post 2018). Langkah Pemerintah Kabupaten menggulirkan program City Tour sudah mendapat respon positif, karena dinilai akan memberi kontribusi dalam peningkatan jumlah kunjungan wisatawan. Akan tetapi, apabila melihat fakta di lapangan yang berbanding terbalik, pemerintah diharapkan bisa melakukan evaluasi program.

\section{Metode}

Penelitian ini juga menggunakan pendekatan deskriptif kualitatif. Metode pengumpulan data yang digunakan dalam penelitian ini yaitu observasi dan wawancara. Lokasi penelitian berpusat pada daya tarik wista yang menjadi rute perkjalanan City Tour di Semarapura. 


\section{Pembahasan}

\section{Perkembangan City Tour Semarapura}

Semarapura yang memiliki destinasi budaya, akan menjadi lebih menarik apabila dalam kunjungan wisatawan, wisatawan dapat memperoleh sesuatu yang membuat perjalanan menjadi berkesan dengan pengalaman berkunjung yang mampu memberikan kesan yang mendalam bagi wisatawan. Menurut Getz (1992) komponen yang harus diperhatikan dalam pengembangan suatu destinasi pariwisata yang dikenal dengan istilah 4A, meliputi Attraction, Accessibility, Ancilarry dan Amenity. Parwisata Kota Semarapura berdasarkan Teori Tourism Area Life-Cycle (TALC) dari Butler (1980), saat ini berada dalam masa development (perkembangan). Hal ini terlihat dari perkembangan pariwisata di Kota Semarapura mulai mengalami peningkatan baik dari segi fasilitas, aktivitas masyarakat dan kunjungan wisatawan

Peluncuran paket wisata City Tour Semarapura pada tanggal 29 April 2016, merupakan salah satu inovasi dari Bapak Bupati Klungkung I Nyoman Suwirta. Pemerintah juga telah melakukan penataan dan perbaikan secara menyeluruh, seperti menata area Sub Terminal Semarapura yang akan digunakan sebagai area parkir bus yang mengantarkan wisatawan, melakukan penataan dan mempercantik monumen Puputan Klungkung, Kertha Gosa dan area Museum Semarajaya serta menata Pasar Seni Semarapura sehinga menjadi lebih bersih, nyaman dan tertata dengan baik. Kegiatan dalam City Tour tidak hanya mengandalkan potensi keindahan alam akan tetapi juga menonjolkan nilai-nilai historis dari sejarah budaya yang dimiliki Klungkung sebagai kota yang memiliki sejarah kerajaan yang panjang. Seperti yang ditujukan gambar berikut ini mengenai peta perjalanan City Tour yang merupakan program terobosan pariwisata di Kota Semarapura Klungkung. 


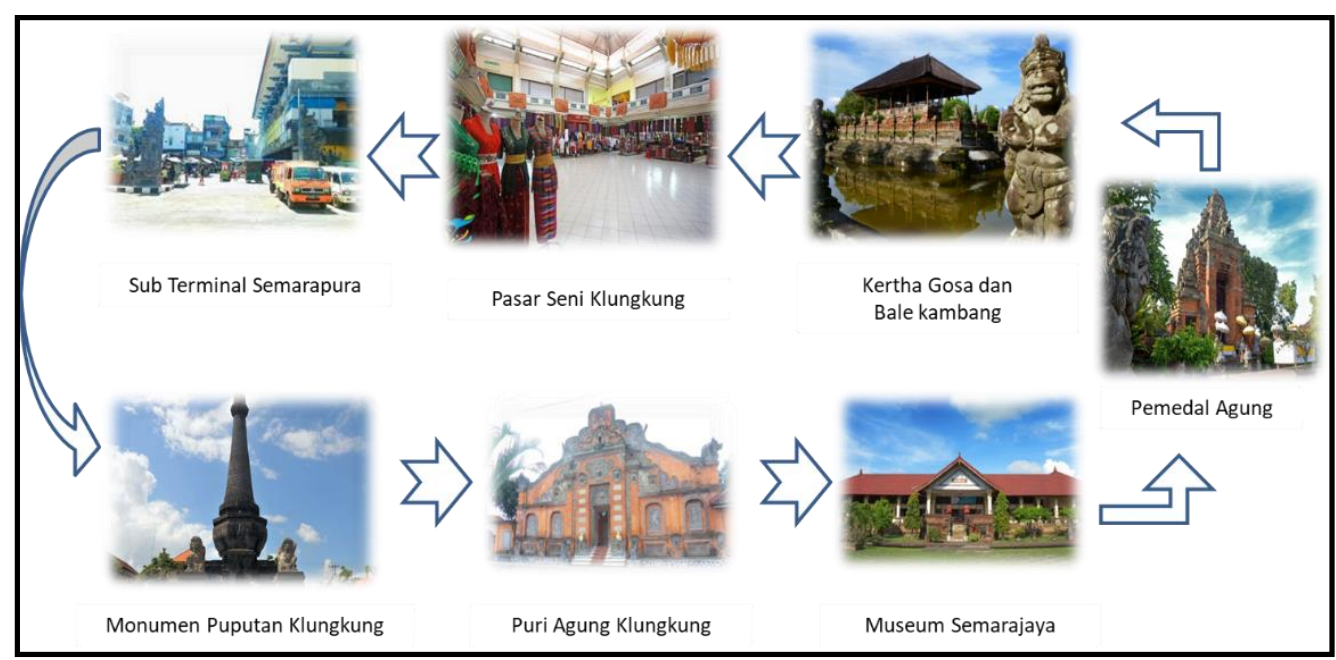

Gambar 1. Rute Awal Pengembangan City Tour

Sumber : Dinas Pariwisata Kabupaten Klungkung

Kunjungan pertama City Tour setelah dari tempat parkir yaitu menuju Monumen Puputan Klungkung. Kunjungan kedua wisatawan diarahkan menuju Puri Agung Klungkung. Kunjungan ketiga adalah museum semarajaya. Kunjungan keempat yaitu Pemedal Agung. Kunjungan Kelima yaitu Kertagosa dan Bale Kambang. Dua Bangunan Kertagosa dan Bale Kambang ada dalam satu kawasan yang mempunyai manfaat yang berbeda pada zaman Kerajaan Klungkung. Kunjungan Keenam yaitu Pasar Seni Klungkung. Pesatnya perkembangan pariwisata pasar klungkung dirubah menjadi Pasar Seni yang ditata sarana dan prasarana serta fasilitas dengan baik dan rapi, dibagi dengan membentuk blok-blok dengan jenis sajian kerajinan endek, songket, rangrang, cepuk, emas, perak, perunggu berupa hasil gamelan, slongsong peluru,kain-kain konveksi serta beraneka ragam kuliner ciri khas Klungkung. Pasar Seni Klungkung merupakan destinasi terakhir dalam City Tour Semarapura, selanjutnya pengunjung atau wisatawan kembali ke starting point di Sub Terminal Semarapura. 
Pemerintah dalam pengembangan City Tour Semarapura mencoba lebih melibatkan partisipasi masyarakat yaitu dengan menambahkan rute City Tour dengan mengunjugi Desa Kamasan. Desa ini merupakan tempat aktivitas kesenian wayang dan logam yang ada di Klungkung.

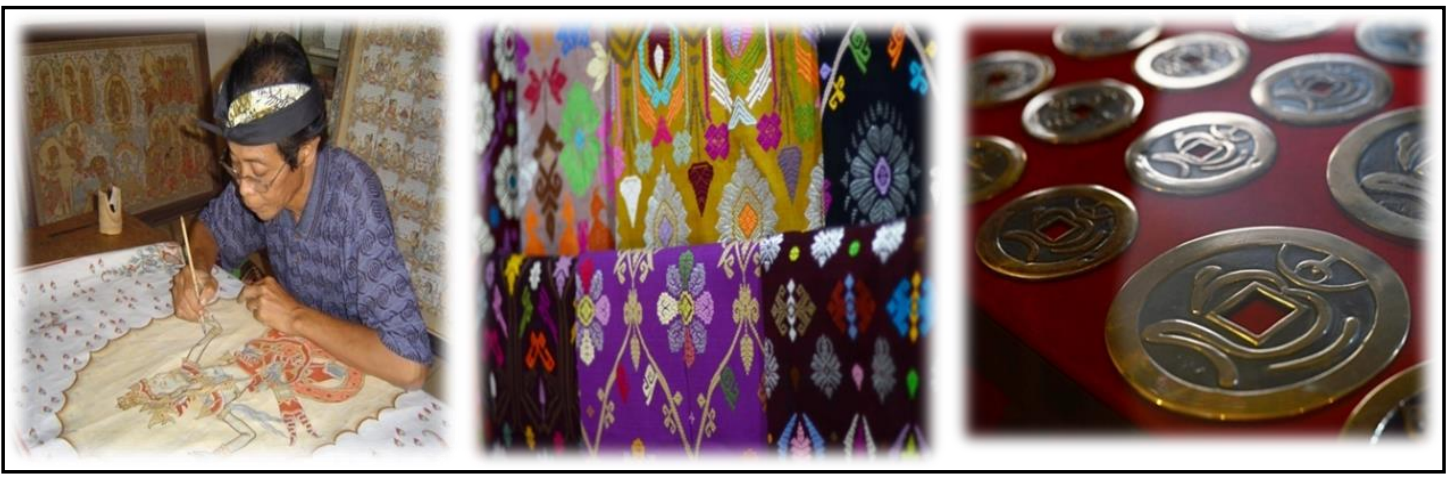

Gambar 2. Kerajinan di Desa Kamasan Klungkung Sumber : Dinas Pariwisata Kabupaten Klungkung

Berdasarkan hasil observasi peneliti dilapangan terkait efisiensi program City Tour pariwisata kota semarapura, bahwa hingga dua tahun berjalan belum mampu meningkatkan jumlah kunjungan wisatawan dan belum mampu menarik wisatawan untuk menikmati program ini. Salah satu alasan karena kota semarapura saat ini masih menjadi tempat persinggahan atau transit bagi wisatawan yang sedang melakukan kunjungan wisata ke Bali tengah ataupun Bali timur. Desa Kamasan kerap tidak diambil wisatawan karena terkendala waktu.

\section{Pengembangan City Tour Semarapura}

Berdasarkan hasil penelitian dan observasi bahwa dengan berbagai potensi wisata yang dimiliki tentunya sangat mungkin untuk mengembangkan pariwisata Kota Semarapura untuk meningkatkan kualitas pariwisata. Upaya yang dapat dilakukan dengan memaksimalkan potensi yang ada tanpa memerlukan dana yang besar yaitu dengan pembuatan paket pariwisata, sehingga bisa menciptakan pariwisata yang berkualitas dengan potensi yang ada. 
The result of a process which implies the satisfaction of all the legitimate product and service needs, requirements and expectations of the consumer, $t$ an acceptable price, in conformity with the underlying quality determinants such as safety and security, hygiene, accessbility, transparency, authenticity and harmony of the tourism activity concerned with its human and natural environment. (UNWTO, 2003).

Indikasi pariwisata dapat dikatakan berkualitas apabila mampu membuat wisatawan lama tinggal lebih lama, dengan kemampuan belanja lebih tinggi, serta memiliki kepedulian terhadap lingkungan alam dan sosial budaya. Hal itu bisa terwujud dengan kontribusi semua pihak dan mampu menerapkan pariwisata yang memanfaatkan sumber daya lokal baik masyarkat lokal, produk lokal dan investasi dari lokal, sehingga roda perekonomian akan semakin hidup dan berkembangan di masyarakat.

\section{Sistemik}

Pengembangan terpadu pariwisata Semarapura dengan pembuatan model atau paket wisata dikaji secara sistemik artinya dalam pengembangannya model ini harus diperhitungkan semua sistem terkait yang berpengaruh dan memiliki kontribusi dalam pengembangannya. Seperti Pemerintah Kabupaten sebagai unit tertinggi, Dinas Pariwisata sebagai penggerak aktivitas kepariwisataan, dinas terkait lainnya yang memiliki kaitan baik secara lansgung maupun tidak langsung contoh Dinas Pertamanan, Dinas Kebersihan, Dinas Ketenagakerjaan dan Instansi lainnya harus dipersiapkan secara tersistem dan terencana. Rancangan model pariwisata yang dikembangkan telah disetujui dan ditetapkan melalui keputusan daerah dalam hal ini PERDA Bupati Klungkung, yang selanjutnya akan dijadikan landasan Dinas Pariwisata dalam melaksanakan rancangan pengembangan pariwisata berkoordinasi dengan Perangkat Desa/Kelurahan yang terlibat untuk membuat alur pengembangannya yang sesuai. 
Pengembangan paket wisata untuk menunjang pariwisata kota semarapura akan mampu berjalan dengan optimal apabila didukung dengan pengambangan sarana akomodasi yang memadai. Sehinggga akan menjadi suatu keterpaduan yang saling menunjang. Pemerintah juga berkewajiban membuatkan suatu sistem regulasi, sistem pengelolaan, sistem pengawasan dengan melibatkan semua pihak. Setalah kegiatan sosialisasi dilakukan pemerintah menyiapkan tempat yang akan digunakan sebagai lokasi pelaksanaan kelas seperti pemanfaatan bangunan Balai Banjar untuk kegiatan kelas menggambar dan menenun, sedangkan untuk kelas pembuatan logam dan gula merah harus langsung ke lokasi pembuatannya.

\section{Holistik}

Pemerintah menyiapkan fasilitas penunjang seperti sarana dan prasarana untuk kegiatan sosialiasi program paket wisata kepada maysrakat, pelaku pariwisata, travel agen, perwakilan media dan pihak-pihak yang terkait secara menyeluruh. Pendekatan secara holistik dilakukan untuk melihat secara menyeluruh semua pihak yang terakait dan akan terdampak dengan pengembangan terpadu pariwisata Kota Semarapura, baik dari sudut pandang Pemerintah sebagai pemegang kebijakan, dinas-dinas terkait sebagai penunjang kegiatan pengembangan, para pekerja pariwisata dilingkungan pariwisata Semarapura, dan masyarakat sekitar yang terdampak terhadap pengembangan pariwisata, dengan penerapan model pariwisata.

Ariani (2018) juga menyatakan bahwa kota terpadu merupakan model untuk gebrakan baru pariwisata perkotaan. Pengembangan pariwisata perkotaan terintegrasi adalah kunci untuk menciptakan paradigma baru pariwisata perkotaan dan meningkatkan jumlah wisatawan, serta untuk mendapatkan kepuasan dan pengalaman wisata, sehingga dapat meningkatkan perekonomian masyarakat. Bhuiyan (2015) juga menyatakan bahwa perekonomian suatu wilayah akan maju apabila mampu memadukan semua sektor pariwisata. Artinya potensi yang dimiliki 
kemudian dilakukan suatu kolaborasi antara Site Attraction dengan Event Attraction akan memberikan suatu pengalaman istimewa bagi wisatawan. Menurut Pearce, et al (1998), motivasi adalah "the total network of biological and cultural forces that give value and direction to travel choice behavior and experience". Jadi dengan memberikan pengalaman luar biasa bagi wisatawan akan mampu meningkatkan memotivasi wisatawan untuk berkunjung.

Pengembangan terpadu pariwisata dijabarkan dengan usulan model yang dirancang 4 jenis paket "Paket Wisata Budaya Semarapura dan Kelas". Paket wisata yang dikembangkan ini merupakan peremajaan paket wisata (City Tour ) sebelumnya, yaitu dengan penambahan kelas wisata untuk memberikan pengalaman bagi wisatawan yang berkunjung ke Semarapura. Berikut dijabarkan masing-masing paket dengan rute perjalanan, estimasi biaya dan waktu yang diperlukan untuk mengikuti paket wisata yang di tawarkan.

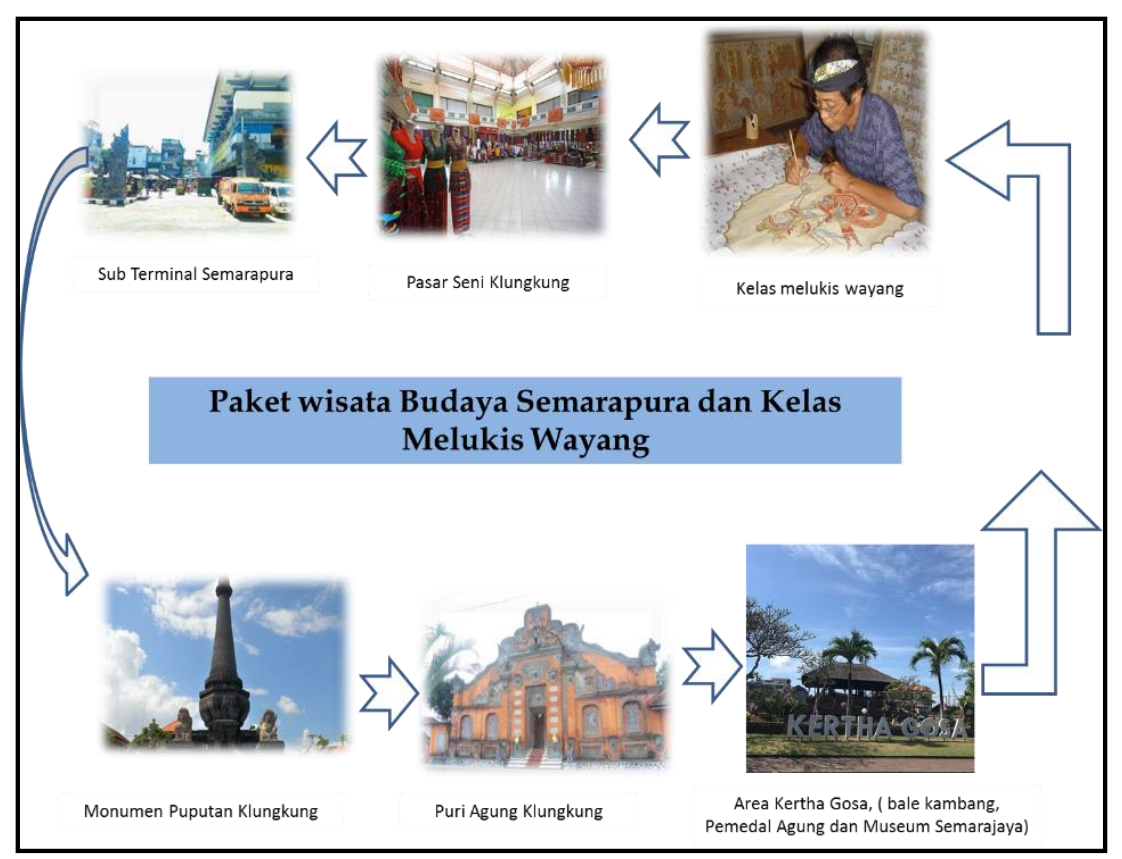

Gambar 3. Rute Paket Wisata Budaya Semarapura dan Kelas Melukis Wayang Sumber : Olahan Peneliti 
Paket yang pertama yaitu Paket Wisata Budaya Semarapura dan Kelas Melukis Wayang. Secara konsep masih sama dengan City Tour sebelumnya jadi wisatawan tetap diajak untuk mengelilingi destinasi budaya yang ada di Kota Semarapura. Kunjungan wisatawan diawali dengan kedatangan di Terminal Semarapura, setalah itu wisatawan melakukan pembelian tiket untuk paket kelas sambil mengunjungi daya tarik wisata Monumen Puputan Klungkung. Selanjutnya wisatawan diarahkan untuk mengunjugi Puri Agung Semarapura, mengunjungi Kertha Gosa yang di dalamnya termasuk Pemedal Agung dan Museum Semarajaya. Kelas melukis wayang dapat dilakukan di bangunan balai yang ada disebelah Kertha Gosa atau memanfaatkan Balai Banjar Kamasan yang ada di Desa Kamasan. Setalah mengikuti kelas melukis wayang wisatawan diantar ke pasar tradisional sebelum kembali ke terminal awal.

Atraksi wisata yang menjadi tambahan pada paket ini yaitu tawaran untuk mengikuti kelas menggambar wayang tradisional Kamasan, yang merupakan potensi unggulan Kabupaten Klungkung. Dalam kelas menggambar ini wisatawan diberikan pembelajaran dari tahap awal mekulis wayang tradisional sampai tercipta suatu karya seni lukis wayang tradisonal. Paket ini bisa dilakukan pada pagi hari (09.00 12.00 wita) ataupun pada sore hari (15.00 - 18.00 wita), paket wisata ini dirancang untuk paket setengah hari (half day tour). Untuk mengikuti paket wisata ini wisatawan akan dikenakan biaya Rp. 250.000 per orang untuk wisatawan dewasa, dan Rp. 150.000 untuk anak-anak (9-15 tahun). Harga paket wisata sudah termasuk perlengkapan untuk melukis wayang dan hasil lukisannya bisa dibawa oleh wisatawan, sehingga memberikan suatu kebanggan bagi wisatawan.

Jenis paket wisata ini memberikan peluang berpartisipasi serta lebih besar bagi masyarakat khususnya masyarakat Kamasan yang kesehariannya memang berkecimpung dalam karya seni lukis wayang. Selain itu, dengan adanya paket ini konservasi budaya Wayang Kamasan akan tetap terjaga, dan semakin dikenal serta 
diminati wisatawan tidak hanya masyarakat Kamasan. Dampak positif paket ini tidak hanya dirasakan dan dinikmati seniman dari Kamasan namun industri-industri kecil yang menyediakan bahan dasar untuk kegiatan melukis Wayang juga memperoleh manfaat positif. Bahkan, tidak menutup kemungkinan sektor lainnya juga akan menerima manfat positifnya.

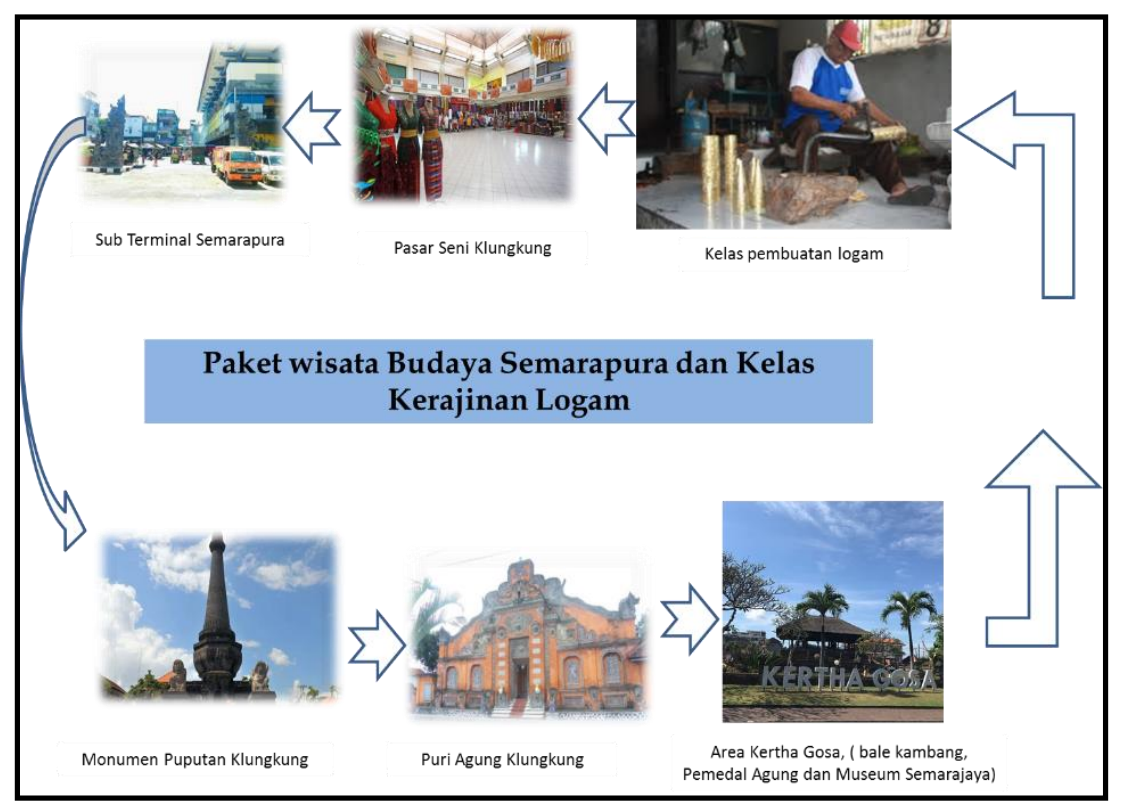

Gambar 4. Rute Paket Wisata Budaya Semarapura dan Kelas Kerajinan Logam Sumber : Olahan Peneliti

Paket wisata kedua yang ditawarkan yaitu Paket Wisata Budaya Semarapura dan Kelas Kerajinan Logam/Uang Kepeng. Jenis paket wisata yang kedua juga memiliki kesamaan dengan City Tour yang telah dikembangkan Kota Semarapura, namun dalam paket ini terdapat terobosan baru dengan penawaran untuk mengikuti kelas pembuatan kerajinan logam. Kunjungan wisatawan diawali dengan kedatangan di Terminal Semarapura, setalah itu wisatawan melakukan pembelian tiket untuk paket kelas sambil mengunjungi daya tarik wisata Monumen Puputan Klungkung. Selanjutnya wisatawan diarahkan untuk mengunjugi Puri Agung Semarapura, mengunjungi Kertha Gosa yang di dalamnya termasuk Pemedal Agung dan Museum Semarajaya. Setalah menikmati atraksi wisata yang ada di Kertha Gosa wisatawan 
diantar untuk mengunjungi Desa Kamasan untuk mengikuti kelas kerajinan logam/uang kepeng. Setalah mengikuti kelas kerajinan logam/uang wisatawan diantar ke pasar tradisional sebelum kembali ke terminal awal.

Klungkung memiliki potensi seni yang sangat beragam salah satunya kerajinan logam/uang kepeng yang bisa ditemukan di Desa Kamasan. Kerajinan logam/uang kepeng yang ada memiliki keunikan tersendiri karena hasil kerajinan logam yang berupa uang kepeng dipergunakan sebagai sarana upacara umat Hindu. Selain itu hasil kerajinan logam lainnya berupa pernak pernik, hiasan rumah dan kesenian lainnya. Dengan mengikuti kelas pembuatan logam/uang kepeng pada paket ini diharapkan mampu memberikan pengalaman kepada wisatawan tentang tata cara pembuatan kerajinan logam sekaligus sebagai media promosi untuk memperkenalkan kerajinan asli Klungkung.

Paket ini bisa dilakukan pada pagi hari (09.00 - 11. 00 wita) ataupun pada sore hari (15.00 - 17.00 wita), paket wisata ini dirancang untuk paket setengah hari (half day tour). Untuk mengikuti paket wisata ini wisatawan akan dikenakan biaya Rp. 200.000 per orang untuk wisatawan dewasa, dan Rp. 100.000 untuk anak-anak (9-15 tahun). Harga paket wisata sudah termasuk perlengkapan untuk mengikuti kelas pembuatan logam.

Paket Wisata yang ketiga yaitu Paket Wisata Budaya Semarapura dan Kelas Menenun, Paket berikutnya yang ditawarkan yaitu penambahan kegiatan menenun pada paket City Tour. Kunjungan wisatawan diawali dengan kedatangan di Terminal Semarapura, setalah itu wisatawan melakukan pembelian tiket untuk paket kelas sambil mengunjungi daya tarik wisata Monumen Puputan Klungkung. Selanjutnya wisatawan diarahkan untuk mengunjugi Puri Agung Semarapura, mengunjungi Kertha Gosa yang di dalamnya termasuk Pemedal Agung dan Museum Semarajaya. Kelas menenun dapat dilakukan di bangunan balai budaya yang ada disebelah Kertha Gosa atau memanfaatkan ruang kosong di area Puri Agung Semarapura. Setelah 
mengikuti kelas menenun wisatawan diantar ke pasar tradisional sebelum kembali ke terminal awal.

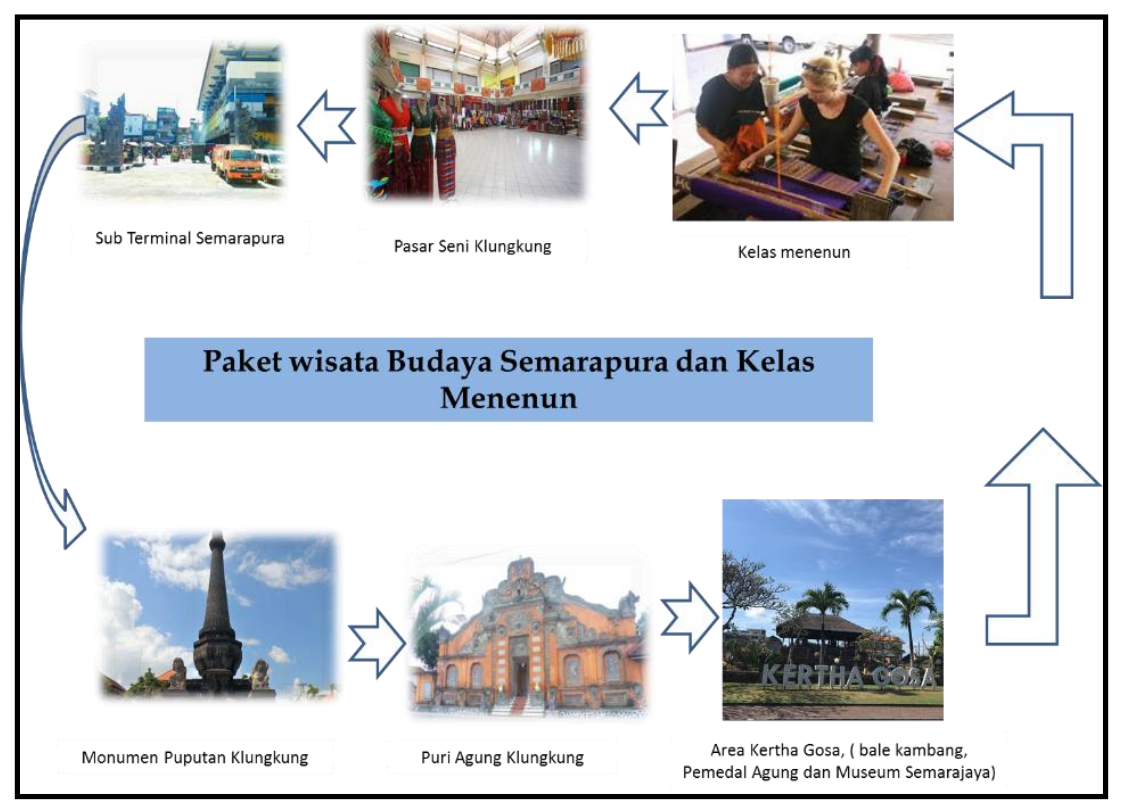

Gambar 5. Rute Paket Wisata Budaya Semarapura dan Kelas Menenun Sumber : Olahan Peneliti

Klungkung yang juga dikenal karena memiliki kain yang khas yaitu kain Endek, yang biasanya digunakan sebagai bahan pakaian. Bahkan, saat ASEAN Leaders Gathering (ALG) di sela-sela Annual Meeting International Monetary Fund (IMF) tahun 2018 (IMF-WB AM 2018), Kamis, 10 Oktober 2018, Presiden Joko Widodo (Jokowi) dan 10 Kepala Negara di Asean, termasuk Presiden World Bank, Jim Yong Kim dan Sekjen PBB Antonio Guterres, mengenakan kain endek ikat catri khas Klungkung. Kain tersebut merupakan karya inovasi putra Klungkung yang bernama Putu Agus Aksara Diantika yang berasal dari Desa Gelgel, Klungkung.

Paket Wisata Budaya Semarapura dan Kelas Menenun bisa dilakukan pada pagi hari (09.00 - 12. 00 wita) ataupun pada sore hari (15.00 - 18.00 wita), paket wisata ini dirancang untuk paket setengah hari (half day tour). Untuk mengikuti paket wisata ini wisatawan akan dikenakan biaya Rp. 300.000 per orang untuk wisatawan dewasa, 
dan Rp. 200.000 untuk anak-anak (9-15 tahun). Harga paket wisata sudah termasuk bahan perlengkapan untuk mengikuti kelas menenun. Kelas menenun tentunya akan menjadi daya tarik unik bagi wisatawan yang ingin mendapatkan pengalaman cara membuat kain yang bermotif indah dengan peralatan sederhana dan menggunakan tangannya sendiri. Selain bermanfaat bagi wisatawan terobosan kelas menenun secara tradisional ini akan bermanfaat bagi pengerajin tenun untuk ikut berpartisipasi menjadi instruktur, sekaligus bagi para pedagang untuk menunjukkan hasil tenun, sehingga aktivitas wisatawan di Pasar Seni Tradisonal Klungkung akan meningkat.

Paket wisata yang keempat yaitu Paket Wisata Budaya Semarapura dan Kelas pembuatan Gula Merah. Kunjungan wisatawan diawali dengan kedatangan di Terminal Semarapura, setalah itu wisatawan melakukan pembelian tiket untuk paket kelas sambil mengunjungi daya tarik wisata Monumen Puputan Klungkung. Selanjutnya wisatawan diarahkan untuk mengunjugi Puri Agung Semarapura, mengunjungi Kertha Gosa yang di dalamnya termasuk Pemedal Agung dan Museum Semarajaya, kemudian wisatawan diantar untuk mengunjungi pasar tradisonal dan kembali ke terminal untuk selanjutnya menuju ke tempat pembuatan gula merah.

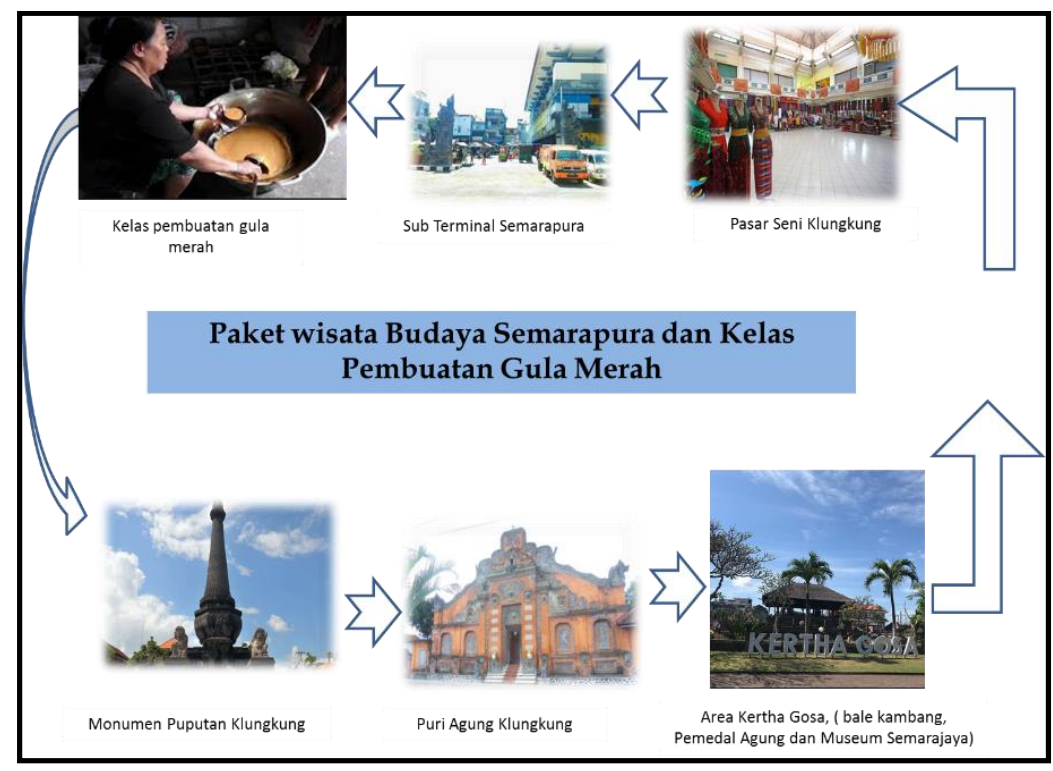

Gambar 6. Rute Paket Wisata Budaya Semarapura dan Kelas Pembuatan Gula Merah Sumber : Olahan Peneliti 
Paket dengan tambahan kelas pembuatan gula merah secara tradisonal merupakan paket tambahan sebagai upaya untuk memperkenalkan daerah Klungkung daratan lainnya yang memiliki potensi unik di bidang bahan kuliner yang nantinya memberikan nuansa klasik bagi wisatawan yang mengikuti kelas ini. Wisatawan setelah mengikuti City Tour akan diajak untuk mengunjungi salah satu desa yang beberapa warganya menggeluti industri pembuatan gula merah (gula aren) secara tradisonal. Desa tersebut terletak di Kecamatan Dawan wilayah Klungkung bagian timur, tepatnya di Desa Besan. Paket ini merupakan paket untuk wisatawan yang memiliki minat khusus pencita kuliner tradisional Bali. Paket ini bertujuan mempromosikan potensi wisata yang ada di bagian Klungkung Timur dan untuk meningkatkan antusiasme para pelaku industri pembuatan gula dalam berkarya.

Paket Wisata Budaya Semarapura dan Kelas pembuatan Gula Merah bisa dilakukan pada pagi hari (09.00 - 11. 00 wita) ataupun pada sore hari (15.00 - 17.00 wita), paket wisata ini dirancang untuk paket setengah hari (half day tour). Untuk mengikuti paket wisata ini wisatawan akan dikenakan biaya Rp. 200.000 per orang untuk wisatawan dewasa, dan Rp. 100.000 untuk anak-anak (9-15 tahun tahun). Harga paket wisata sudah termasuk menikmati jajanan tradisional yang menggunakan gula merah sebagai pemanisnya. Paket ini tidak hanya menawarkan wisatawan belajar pembuatan gula saja namun, wisatawan juga dapat menikmati atraksi dari bagaimana pengerajin gula merah memanjat pohon kelapa secara tradisional sebagai bahan untuk pembuatan gula. Selain mengikuti kelas pembuatan gula merah bagi wisatawan, masyarakat juga dapat menawarkan berbagai kuliner tradisonal Bali yang menggunakan gula merah sebagai pemanisnya.

Keempat model ini dirancang dalam waktu yang cukup untuk half day tour. Kegiatan ini dapat dilaksanakan pagi atau sore hari, paket ini disusun dengan mengunjungi wisata budaya yang dikombinasikan dengan daya tarik wisata lainnya yang memiliki dimensi budaya, seperti aktivitas belajar budaya bagi wisatawan. 
Kombinasi wisata budaya dengan pengalaman mengikuti kelas pembelajaran akan memberikan pengalaman yang tak terlupakan bagi wistawan, dan meningkatkan nilai prestise bagi wisatawan.

\section{Interdisipliner}

Pengembangan model paket wisata ini perlu dilakukan kajian-kajian dari berbagai bidang ilmu, dengan pendekatan interdisipliner, merupakan alternatif yang cocok untuk melakukan kajian-kajian dari berbagai sudut pandang untuk memperoleh berbagai masukan dalam pengembangan terpadu pariwisata di Kota Semarapura. Keberhasilan suatu program tidak akan terjadi apabila tidak dilakukan secara bersama-sama dan saling terkait. Pengembangan terpadu pariwisata Semarapura dengan perbaikan model pariwisata diperlukan kajian dari beberapa ilmu dan aspek, seperti kajian terhadap dampak ekonomi dengan adanya pengembangan pariwisata, kajian dari segi sosial budaya terdahap dampak pengembangan pariwisata Kota Semarapura, kemudian kajian dari sisi lingkungan yang terdampak akibat pengembangan pariwisata.

Program pengembangan terpadu pariwisata Kota Semarapura akan berjalan optimal apabila dilakukan secara total dan digarap serius, sehingga diperlukan suatu badan pengelola yang nantinya berfungsi dan memiliki kewenangan dalam mengelola, mengembangkan dan menjaga keberlanjutan paket wisata yang dikembangkan. Anggota dari bada pengelola pariwisata ini haruslah dari berbagai kalangan dan latar belakang yang berbeda, seperti perwakilan dari pemerintahan dalam hal ini Dinas terkait, perwakilan dari kelompok sadar wisata, perwakilan dari pelaku wisata baik pengerajin (wayang, kain tenun, logam dan gula merah), akademisi, masyarakat terdampak dan perangkat desa. Artinya orang-orang yang duduk sebagai anggota badan pengelola berasal dari berbagai disilpin ilmu (interdisipliner) dan membawa berbagai sudut pandang, sehingga apabila kedepannya terdapat suatu permasalahan akan amampu diselesaikan secara 
bersama-sama dan menyeluruh, melalui kontribusi semua pihak melalui perwakilannya.

Badan pengelola juga berperan untuk menyiapkan pembinaan, penyuluhan tentang rancangan paket wisata yang akan dijalankan. Menunjuk instruktur yang berkompeten dibidangnya untuk membina dan mendampingi wisatawan saat mengikuti paket kelas wisata. Menyiapkan dan menetapkan jadwal pelaksanaan uji coba paket, serta melakukan promosi paket wisata dengan melakukan kerja sama dengan berbagai media cetak maupun elektronik, serta travel agen yang ada. Tugas terakhir dari badan pengelola setelah program dilaksanakan yaitu melakukan kontrol dan evaluasi kegiatan untuk meningkatkan kualitas program pariwisata dan memberikan kepuasan terhadap wisatawan dengan pengalaman yang autentik.

\section{Partisipatori}

Dukungan masyarakat merupakan pondasi yang penting dalam pengembangan pariwisata, dukungan tidak hanya berupa uang atau ikut bekerja namun dukungan juga dapat dilakukan dengan dukungan moril, upaya pelestraian, ikut mempromosikan dan kegiatan lainnya yang berdampak terhadap pariwisata. Pariwisata Kota Semarapura secara berkala mengalami peningkatan kualitas untuk memberikan citra positif dan kenyamanan bagi wisatawan yang sedang berkunjung ke daya tarik wisata yang ada di Kota Semarapura. Pemerintah Kabupaten Klungkung telah melakukan berbagai upaya untuk meningkatkan kualitas pariwisata di Kabupaten Klungkung khususnya di Kota Semarapura, yang merupakan pusat kota.

Pengembangan akomodasi wisata untuk mendukung program paket wisata yang dirancang dengan lebih memanfaatkan rumah-rumah pemukiman penduduk setempat, tentunya dengan tetap mengutamakan kualitas, penampilan, serta sarana dan prasarana yang diperlukan sesuai dengan standar yang berlaku. Hal ini juga 
memberikan kesempatan terhadap masyarakat untuk ikut berpartisipasi melalui pemberdayaan masyarakat sehingga dapat meningkatkan kualitas sumber daya masyarakat. Selain itu pengawasan terhadap pelaksanaan paket akan lebih mudah dilakukan karena masyarakat akan terjun langsung sebagai pelaku dan penerima hasil kegiatan pariwisata.

Pemerintah juga bertugas menyiapkan kegiatan pembelajaran untuk anakanak muda daerah yang ingin menjadi penerus kesenian yang ada, tentunya dengan menyiapkan instruktur yang telah dipilih oleh pemerintah, selain pembelajaran secara teknis intruktur kelas juga diberikan pembelajaran bahasa untuk memperlancar komunikasi dengan wisatawan yang mengikuti kelas. Dengan demikian pengelolaan dan pengembangan pariwisata Kota Semarapura akan terpadu dan akan melibatkan peran serta masyarakat, sehingga manfaat pariwisata akan mampu meningkatkan kesejahteraan masyarakat.

\section{Simpulan}

Pengembangan terpadu pariwisata Kota Semarapura dilakukan dengan merancang model pengembangan paket wisata dengan peremajaan konsep City Tour yang sudah ada dengan penambahan kelas (pembelajaran) bagi wisatawan. Diajukan 4 paket City Tour dengan peremajaan paket yang ada sebelumnya dan lebih melibatkan partisipasi masyarakat dan semua pemangku kepentingan, sehingga dengan pengembangan paket wisata kelas dapat meningkatkan partisiapsi masyarakat dan meningkatkan perekonomian masyarakat Kota Semarapura.

\section{Ucapan Terima Kasih}

Pada kesempatan ini perkenankanlah peneliti mengucapkan terima kasih yang sebesar-besarnya kepada Prof. Dr. Ir. Syamsul Alam Paturusi, MSP, pembimbing utama yang dengan penuh perhatian telah memberikan dorongan, semangat, 
bimbingan, dan saran selama peneliti mengikuti program magister, khususnya dalam penyelesaian Jurnal ini. Terima kasih sebesar-besarnya pula peneliti sampaikan kepada Dr. Drs. I Nyoman Sunarta, M.Si., Pembimbing II yang dengan penuh perhatian dan kesabaran telah diberikan bimbingan dan sarannya kepada peneliti.

\section{Daftar Pustaka}

Ahmed Bhuiyan, Miraj. 2015. Integrated Tourism Sector in South-Eastern Asian (Mainland) Countries: A Pathway to Develop for Economic Betterment. International Journal of Business Administration Vol. 6, No. 1; 2015.

Agusintadewi, Ni Ketut. Konservasi Puri Smarapura di Klungkung, Bali Seminar Ikatan Peneliti Lingkungan Binaan Indonesia (IPLBI) 1, B 297-204 https://doi.org/10.32315/sem.1.b297.

Agus, Tria Pradnyana Udayana, I Made Agus Wirawan dan I Made Gede Sunarya. 2017. Pengembangan Aplikasi Panduan Pariwisata Berbasis Android di Kabupaten Klungkung.' Kumpulan Artikel Mahasiswa Pendidikan Teknik Informatika (KARMAPATI).

Ariani, V. 2018. 'Integrated city as a model for a new wave urban tourism'. IOP Conference Series: Earth and Environmental Science. 126 (2018) 012187.

Butler, R.W. 2011. Contemporary Tourism Reviews. Woodeaton: Goodfellow Publishers Limited (http://www.goodfellowpublishers.com).

Getz, Donald. 1992. Tourism Planning and Destination Life Cycle. Annal of Tourism Research. 19: 752-770.

Kurnia , An-nisaa Widianti dan Anung Bambang Studyanto.2018. Kertha Gosa Court Hall of Klungkung Bali as an effort to conserve cultural heritage based on traditional culture. Friendly City 4 'From Research to Implementation For Better Sustainability' IOP PublishingIOP Conf. Series: Earth and Environmental Science 126 (2018).

Manuaba, A. 2006. Totall Approach is a Must for Small and Medium Enterprises to Attain Sustainable Working Conditions and Environment, with Special Reference to Bali, Indonesia. Industrial Health 2006, 44, 22-26.

Paturusi, Syamsul Alam.2008. Perencanaan Kawasan Pariwisata. Denpasar : Press UNUD. 
Pemerintah Kabupaten Klungkung. 2016. Sejarah Kertha Gosa http://www.klungkungkab.go.id/index.php/baca-pariwisata/84/kerta-gosa diakses 25 September 2016.

Puja Astawa I.B.G. I.GP Wirawan. I Made Adhika. 2002. Pola Pengembangan Pariwisata Terpadu Bertumpu Pada Model Pemberdayaan Masyarakat di Wilayah Bali Tengah. Denpasar: Universitas Udayana.

Putra, I.K.A.W., Treman, I.W. and Suratha, I.K., 2014. Eksistensi Objek Wisata Kertha Gosa di Kabupaten Klungkung (Suatu Kajian Geografi Pariwisata). Jurnal Pendidikan Geografi Undiksha, 5(1).

Rai Sita, A.A. Laksmi. 2013. Nuansa Kearifan Lokal Situs Kertha Gosa Dalam Mengkonstruksi Jatidiri Pada Era Global'The Wisdom of Kertha Gosa's Archaeological Remains and Identity Construction in Global Era' Forum Arkeologi Volume 26, Nomor 3, November 2013 (207 - 216).

Rossi Evita, I Nyoman Sirtha,I Nyoman Sunartha. 2012. Dampak Perkembangan Pembangunan Sarana Akomodasi Wisata Terhadap Pariwisata Berkelanjutan di Bali. Lurnal Ilmiah Pariwisata. Volume 2 No.1 Hal 109-222 September 2012.

Sidemen, Ida Bagus dkk. 2001. Sejarah Klungkung; Dari Smarapura sampai Puputan. Klungkung: Pemerintah Kabupaten Klungkung.

Singarimbun, Masri dan Sofian Effendi, 2006, Metode Penelitian Survei (Editor),LP3ES, Jakarta.

Trisna Semara, I Made. 2013. Strategi Perencanaan Pembangunan Pariwisata Kertagosa Di Kabupaten Klungkung"Jurnal Ilmiah Hospitality Management", Vol. 4 No. 1 Juli-Desember 2013,hlm 39.

Tung, V. W. S., and Ritchie, J. R. B. (2011). Exploring the essence of memorable tourism experiences. Annals of Tourism Research, 38(4), 13671386.

Warsika, I Gst. Made. 1986. Kertha Gosa Selayang Pandang. Klungkung: Pemerintah Daerah Tingkat II Klungkung.

Wirawan, A.A. Bagus dkk. 2002. Ida I Dewa Agung Istri Kanya; Pejuang Wanita Rakawi Melawan Kolonialisme Belanda di Kerajaan Klungkung abad XIX. Klungkung: Pemerintah Kabupaten Klungkung.

Yayasan Smarapura Cultural Heritage Trust (2005) Pelestarian Warisan Budaya Smarapura. Klungkung: Yayasan Pelestarian Warisan Kebudayaan Smarapura. 


\section{Profil Penulis}

I Nengah Alit Nuriawan, S.S.,M.Par. adalah alumni Program Magister Kajian Pariwisata Universitas Udayana, saat ini tercatat sebagai dosen tetap pada Program Studi Industri Perjalanan, Fakultas Dharma Duta, Universitas Hindu Negeri I Gusti Bagus Sugriwa. Minat studi adalah penelitian pengembangan pariwisata budaya melalui city tour.

Syamsul Alam Paturusi adalah Guru Besar Perancangan Kota pada Jurusan Arsitektur, Fakultas Teknik Unud dan dosen Prodi Magister Kajian Pariwisata, saat ini menjabat sebagai sekretaris program studi Magister Kajian Pariwisata, Universitas Udayana. Selain itu, beliau juga aktif mengajar sebagai dosen pada S1 dan S2 Teknik Arsitektur Unud; S3- Pariwisata, Unud; dan S2-S3 Ilmu Lingkungan, Unud. Sarjana (S1) di Arsitektur Universitas Hasanuddin, Makassar, jenjang Magister (S2) di PWK ITB, Bandung, dan jenjang Doktor (S3) di Université de Pau et des Pays de l'Adour, Prancis.

I Nyoman Sunarta adalah Dosen Magister Pariwisata Universitas Udayana, dan kini menjabat sebagai Dekan Fakultas Pariwisata Universitas Udayana. Minat penelitian Sunarta adalah ecotourism dan hidrology. 